\title{
NÁVRH METODIKY NA ZABEZPEČENIE OSVETLENIA ZARIADENIA STAVENISKA
}

\author{
PROPOSAL METHODOLOGY FOR ENSURING THE LIGHTING \\ OF THE CONSTRUCTION EQUIPMENT
}

\author{
doc. Ing. Eva Jankovichová, PhD. ${ }^{1 *}$; Ing. Minh Nguyen Tien, PhD. ${ }^{1}$; \\ Ing. Martin Hanko PhD. ${ }^{1}$ \\ ${ }^{1}$ Slovenská technická univerzita v Bratislave, Stavebná fakulta, Radlinského 11, 81005 Bratislava, Slovensko \\ * korešpondenčný autor: eva.jankovichova@stuba.sk
}

\section{ABSTRAKT}

V dobe, ked’ environmentálne problémy exponenciálne zvyšujú obavy po celom svete a vyzývajú k hl'adaniu udržatel'ných riešení, je viac ako potrebné orientovat' sa na nové možnosti využitia obnovitel'ných zdrojov energie aj v sektore stavebníctva. Obnovitel'né zdroje energie prispievajú k posilneniu a diverzifikácii štruktúry jednotlivých odvetví hospodárstva, podporujú inovácie a rozvoj informačných technológií, otvárajú priestor pre nové smerovania a sú jedným z pilierov budovania znalostnej ekonomiky.

Ciel’om článku je prezentácia návrhu metodiky na zabezpečenie osvetlenia zariadenia staveniska z obnovitel’ných zdrojov energie v období prípravy a realizácie stavebných objektov.

Klúčové slová: Obnovitel'né zdroje energie, zariadenie staveniska, veterné turbíny

\section{ABSTRACT}

At a time when environmental problems are exponentially raising concerns around the world and calling for sustainable solutions, it is more than necessary to focus on new possibilities for the use of renewable energy sources in the construction sector as well. Renewable energy sources contribute to the strengthening and diversification of the structure of individual sectors of the economy, support innovation and the development of information technologies, open up space for new directions and are one of the pillars of building a knowledge economy.

The aim of the article is to present a proposal for a methodology for ensuring the lighting of construction site equipment from renewable energy sources in the period of preparation and implementation of buildings.

Key words: Renewable energy sources, construction equipment, wind turbines

\section{1 ÚVOD}

Inovácie hýbu svetom a vznikajúce technológie menia prostredie, v ktorom žijeme a tým aj celú našu spoločnost'. Inovácie v energetike sú vel'mi dôležité - nakladanie s energiami, ich využitie, a to z pohl'adu trvalo udržatel'ného rozvoja, ako aj environmentálneho dopadu. [3] Zníženie emisií skleníkových plynov, zvýšenie energetickej efektívnosti a podielu obnovitel'ných zdrojov, prechod na obehovú ekonomiku a udržatel'ná doprava sú kl'účové priority v zelenej ekonomike. Vel'ký investičný dlh má Slovensko najmä v dobudovaní kanalizácií a vodovodov, environmentálnych zátažiach či nízkej 
energetickej efektívnosti budov. Zelené politiky sú nevyhnutné pre pružnú reakciu ekonomiky na mega trendy ako dekarbonizácia či nové technológie. Reforma regulácií vytvorí priestor na zvýšenie podielu obnovitel'ných zdrojov energie, flexibilnejšie a odolnejšie siete. Komplexná obnova budov prispeje k zvýšeniu energetickej efektívnosti. [2]

Využívanie obnovitel'ných zdrojov energie (OZE) prináša pozitívne prínosy na celú spoločnost'. Zvyšuje bezpečnost' a diverzifikáciu dodávok energie a súčasne znižuje závislost' ekonomiky od nestabilných cien ropy a zemného plynu.

\section{SÚČASNÝ STAV VYUŽíVANIA OZE V EÚ A NA SLOVENSKU}

Pri prechode na konkurencieschopný, bezpečný a udržatel'ný energetický systém bude najdôležitejšiu úlohu zohrávat' energia z obnovitel'ných zdrojov. V oblasti využivania OZE je ciel’om každého štátu zabezpečit' zvýšenie podielu OZE na hrubej konečnej energetickej spotrebe podl'a vnútorných ciel'ov. Odvážnejší ciel', záväzný pre celú EÚ je dosiahnut' do roku 2030 podiel minimálne 27 \% energie z obnovitel'ných zdrojov podporený trhovo orientovanejším prístupom umožňujúcim nástup vznikajúcich technológií. Je to významný prínosom pre vyváženie trhu s energiou, využívanie miestnych zdrojov energie, rast a zamestnanost'. Ciel' v oblasti energie z obnovitel'ných zdrojov stanovený na úrovni EÚ je nevyhnutný na stimulovanie pokračujúcich investícií do tohto odvetvia. Do vnútroštátnych ciel'ov sa však neprenesie prostredníctvom právnych predpisov EÚ, čím sa členským štátom ponechá flexibilita pri transformácii energetického systému, ale podl’a vnútroštátnych preferencií a okolností. [1]

\subsection{Podiel OZE v EÚ a na Slovensku}

Podl’a posledných údajov za rok 2018 chýbali Slovensku a tiež EÚ ako celku dve percentá k dosiahnutiu ciel'ov pre podiel obnovitel'ných zdrojov energie, ktoré sú stanovené do konca tohto roka. Najvyšší podiel dosiahli Švédi a Fíni.

Zatial' čo dvanást' štátov EÚ vrátane susedného Česka už naplnilo svoje národné ciele do roku 2020 a štyri krajiny boli pomerne blízko, niektoré krajiny vykazujú vel'ké problémy. Najd’alej od naplnenia svojho tohtoročného ciel’a bolo Holandsko, Francúzsko a Írsko.

Podiel OZE na hrubej koncovej spotrebe energie na Slovensku bol podl'a Eurostatu v roku 2018 na úrovni $11,9 \%$, čo predstavovalo medziročný nárast o 0,4 \%. Najbližšie $\mathrm{k}$ naplneniu nášho národného 14-percentného ciel'a sme boli v roku 2015, kedy sa podiel obnovitel’ných zdrojov vyšplhal na úroveň $12,9 \%$.

Zo všetkej energie, ktorá sa v roku 2018 spotrebovala v celej EÚ, pochádzalo z obnovitel’ných zdrojov rovných 18 \%. Ako ukazuje nasledujúci graf, podiel zelenej energie v Únii sa medzi rokmi 2004 až 2018 viac ako zdvojnásobil.

V celkovom podiele OZE sa zohl'adňujú tri sektory - elektrina, doprava a vykurovanie spolu s chladením. Najvyšší podiel OZE dosahuje Slovensko v elektrine - v roku 2018 bol tento podiel na úrovni $21,50 \%$. Pokial' ide o teplárenstvo, resp. chladenie, podiel obnovitel'ných zdrojov energie v tomto sektore dosiahol v danom roku výšku 10,6 \%. V sektore dopravy sa zelená energia využívala najmenej, v roku 2018 zostala pod úrovňou 7 \%. Celková hrubá koncová spotreba energie na Slovensku podl’a Eurostatu medziročne o niečo klesla, a to na úroveň $11,9 \%$. 
Najvyšší podiel obnovitel'ných zdrojov v roku 2018 dosiahlo Švédsko, kde z OZE pochádzala viac ako polovica všetkej spotrebovanej energie (54,6 \%). S väčším odstupom d’alej nasledujú Fínsko (41,2 \%), Lotyšsko (40,3 \%), Dánsko (36,1 \%) a Rakúsko (33,4 \%). Na opačnom konci rebríčka skončili Holandsko (7,4 \%), Malta (8 \%), Luxembursko $(9,1 \%)$ a Belgicko $(9,4 \%)$.

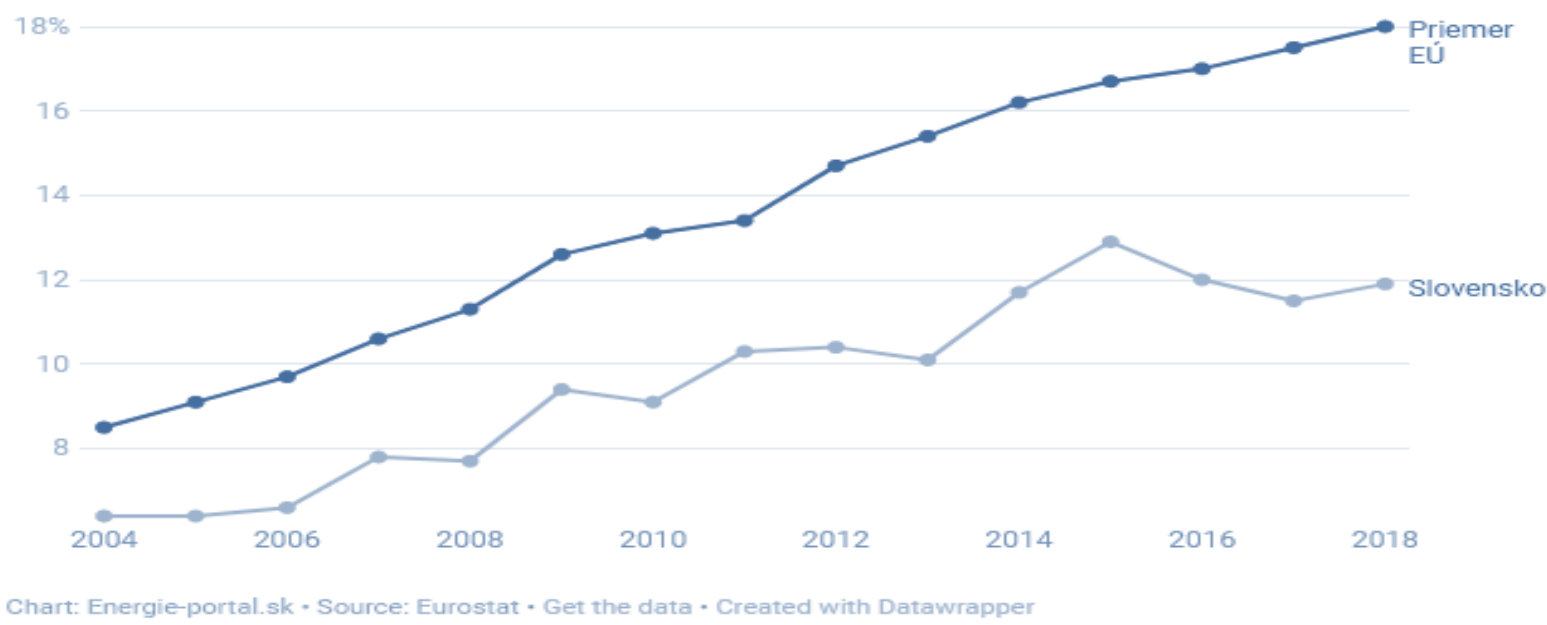

\section{Graf 1 Podiel OZE na Slovensku a v EÚ-28 [6]}

Zo 16 krajín, ktoré ciel' pre rok 2020 ešte nedosiahli, za svojím záväzkom najvýraznejšie zaostáva Francúzsko a Holandsko, ktoré od ciel'ového podielu OZE v roku 2018 delilo viac ako pät' percentuálnych bodov.

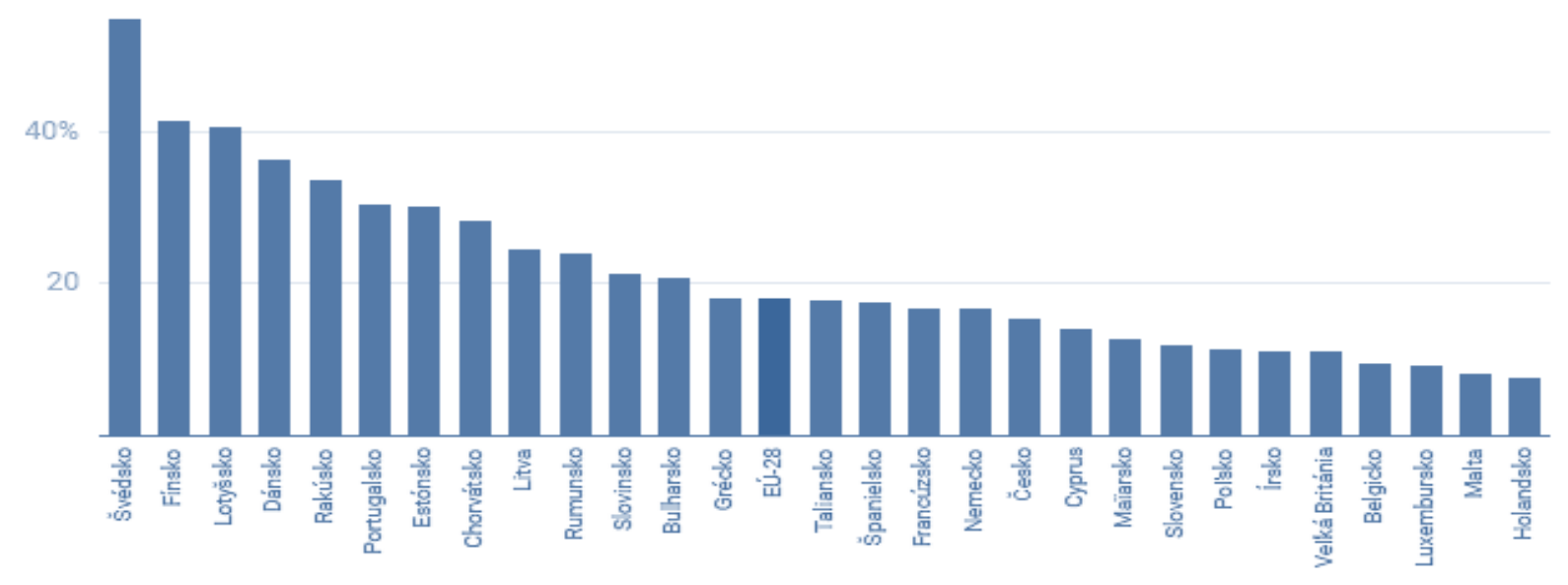

Chart: Energie-portal.sk - Source: Eurostat - Get the data - Created with Datawrapper

\section{Graf 2 Podiel OZE na koncovej spotrebe energií v EÚ-28 [6]}

Z celkového objemu elektriny, ktorá sa $\mathrm{v}$ roku 2018 spotrebovala $\mathrm{v} E U$, pochádzala z OZE približne jedna tretina (32\%). Najvyšší podiel na spotrebe elektriny mali OZE v susednom Rakúsku (73,1 \%), d’alej vo Švédsku $(66,2 \%)$ a Dánsku $(62,4 \%)$.

$\mathrm{Na}$ Slovensku pochádzala $\mathrm{z}$ obnovitel'ných zdrojov $\mathrm{v}$ roku 2018 viac ako pätina spotrebovanej elektriny (21,5 \%), v Česku (13,7 \%), Pol'sku (13 \%) aj Mad'arsku (8,3 \%) to bolo menej. 
Podiel OZE v spotrebe elektriny rastie vo zvyšku EÚ rýchlejšie ako na Slovensku. Kým ešte v roku 2008 bol podiel OZE na Slovensku a priemer EÚ zhodne na úrovni približne 17 \%, v nasledujúcej dekáde u nás vzrástol iba mierne, kým číslo za celú EÚ vzrástlo takmer na dvojnásobok.

Rast objemu elektriny vyrobenej z OZE v období rokov 2008 až 2018 do vel'kej miery odráža expanziu troch druhov OZE naprieč EÚ, predovšetkým expanziu veternej energie, ale aj solárnej energie a pevných biopalív.

Veterná energia dosiahla vo výrobe elektriny podl'a čísel za rok 2018 najvyšší podiel spomedzi všetkých obnovitel'ných zdrojov. Produkcia veternej energie z hladiska objemu vzrástla od roku 2008 viac ako trojnásobne, v prípade solárnej energie je to až 17-percentný nárast.

Krajiny strednej a juhovýchodnej Európy disponujú potenciálom na zvýšenie podielu obnovitelných zdrojov oproti číslam stanoveným v národných klimaticko-energetických plánoch. Napríklad v prípade Slovenska, ktoré si stanovilo ciel' $19 \%$, môže byt' tento podiel na úrovni $23 \%$, uvádza Medzinárodná agentúra pre obnovitel'né zdroje IRENA (Graf 3).

Najväčší potenciál na Slovensku zo všetkých OZE zdrojov má fotovoltika, a to až takmer o vyše $2 \mathrm{GW}$ viac do roku 2030 ako počíta štátna koncepcia. Zdvojnásobenie kapacity je možné aj pre veterné elektrárne.

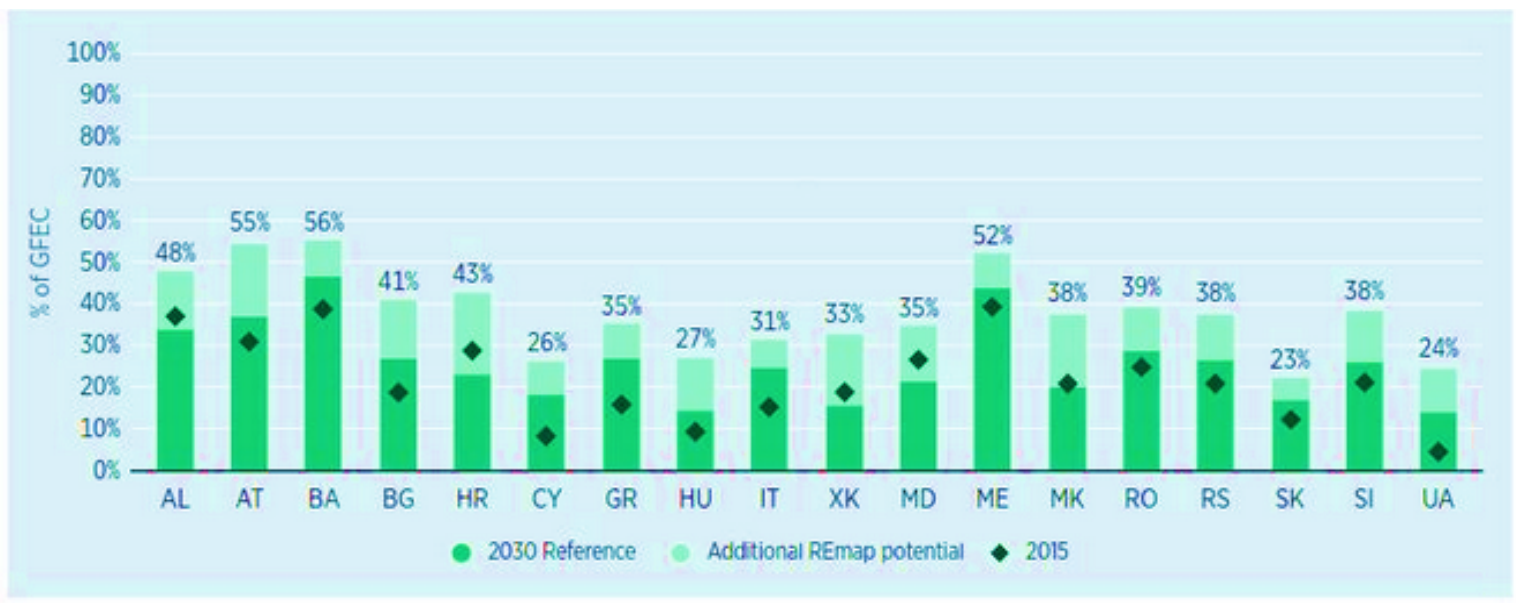

Graf 3 Stav a ciele v podiele OZE na spotrebe energie v krajinách strednej a východnej Európy [7]

Potenciál obnovitel'nej energie na Slovensku je pomerne dobre zmapovaný. Z mapy slnečného svitu možno získat' informácie o tom, kde a aká energia sa dá využit'. Podobná mapa existuje pre veterné podmienky, hoci sa zameriava skôr na lokalizáciu chránených areálov a vzdialenosti od budov a infraštruktúry. Takto by sme vedeli využit' asi 4 \% územia. To sa môže zdat' málo, no v skutočnosti je to pomerne vel'ká plocha. Ale je na investoroch, aby posúdili miestne podmienky a potenciál.

Od augusta 2015 sa v rámci operačného programu Kvalita životného prostredia (OPKZP) v súlade s národným projektom Zelená domácnostiam, zavádzajú nové všeobecné podmienky na podporu využitia obnovitel'ných zdrojov energie $\mathrm{v}$ domácnostiach, ktorých ciel’om je podpora inštalácie malých zariadení pre rodinné domy a bytové domy.

Malým zariadením pri výrobe elektriny je zariadenie s výkonom do $10 \mathrm{~kW}$ na výrobu elektriny alebo tepla z OZE. Medzi tieto zariadenia patria fotovoltaické panely, veterné turbíny, slnečné kolektory, kotly doi.org/10.51704/cice.2020.vol6.iss2.pp51-58 
na biomasu a tepelné čerpadlá, pričom konkrétny výrobný typ zariadenia musí byt' uvedený v zozname oprávnených zariadení, ktorý vedie SIEA. [8]

\section{NÁVRH METODIKY IMPLEMENTÁCIE OZE NA ZARIADENIE STAVENISKA}

Ak hovoríme o zvyšovaní potreby energie, musíme mobilizovat' všetky dostupné zdroje, a to nie len klasické zásoby organických palív, vodnú energiu a štiepne materiály, ale aj obnovitel'né zdroje energie, ktorých uplatnenie je podl'a súčasného stavu vedy a techniky možné. Obnovitel’né zdroje energie majú ten najdôležitejší znak, že sú to ekologicky čisté zdroje. Využívanie alternatívnych zdrojov energie už od začiatku výstavby by mohlo prispiet' nie len k zvyšovaniu podielu OZE ale aj k zníženiu spotreby energie na stavbe.

Dôležitý krok na začiatku riešenia problematiky je stanovit’ správny postup, určenie jednotlivých krokov. Problematika ohl'adom využívania obnovitel'ných zdrojov energie je vel'mi rozsiahla. Autori sa zamerali iba na využívanie veternej energie. V samotnej práci je navrhnutá metodika ako postupovat' pri navrhovaní veterných turbín pre potreby zásobovania zariadenia staveniska elektrickou energiou (Obr. 1), nie len z konštrukčno-technologického ale aj z ekonomického hl'adiska, na akejkol'vek stavbe, ktorá spíňa vybrané kritériá. Prvým krokom bolo zadefinovanie vybraných kritérií a určenie okrajových podmienok. Súčast'ou návrhu bola aj experimentálna čast' riešenia problematiky samostatné meranie na vybranej stavbe.

Definovanie, analýza vybraných kritérií a určenie okrajových podmienok

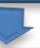

Výber vhodného typu OZE na implementáciu -veterné turbíny

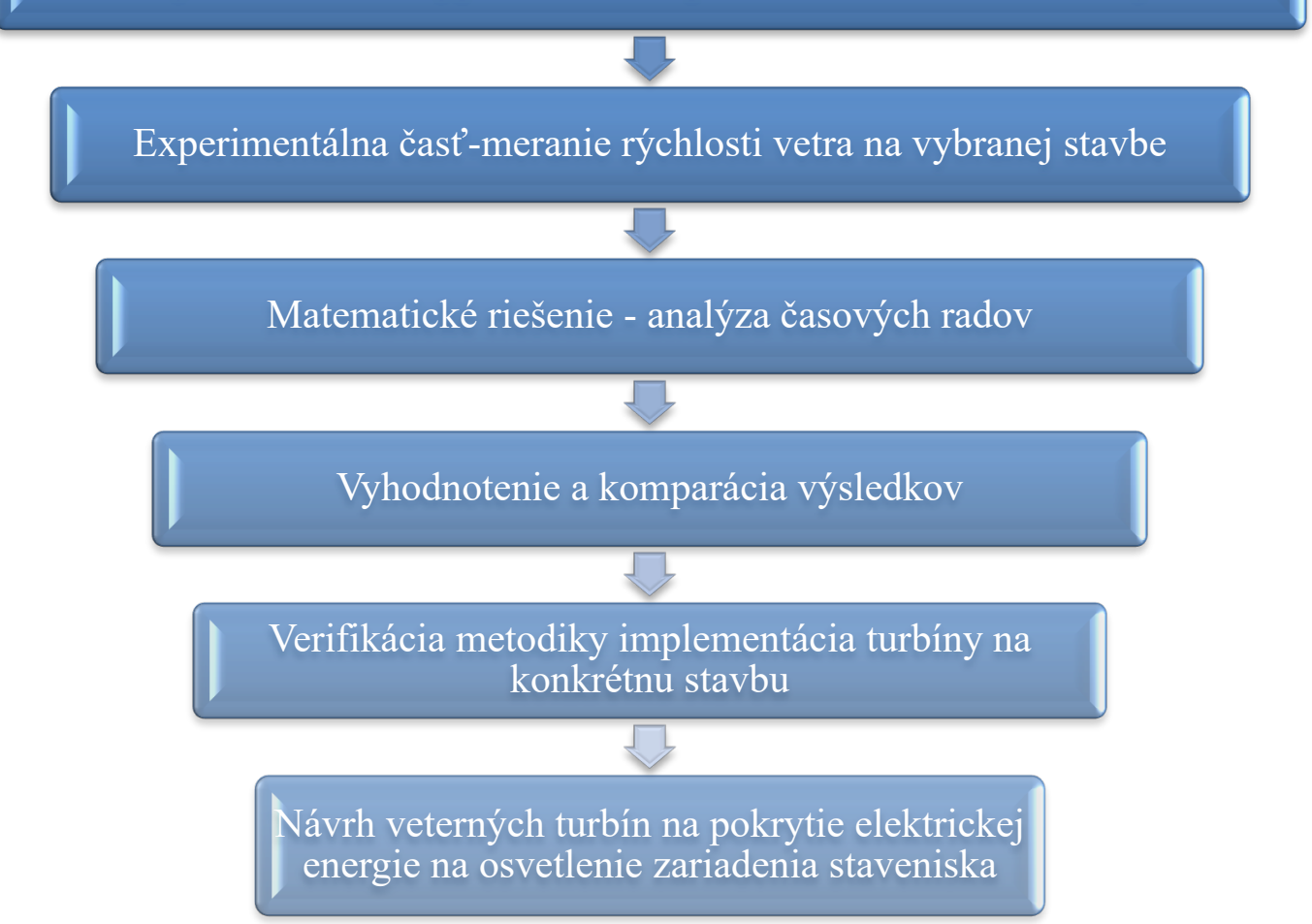

Obr. 1 Postup návrhu metodiky implementácie OZE na zariadenie staveniska, zdroj: autor 


\subsection{Vybrané kritériá a okrajové podmienky}

Každý druh obnovitel'ného zdroja energie, t. zn. aj veterná energia má jedinečný charakter, ktorý vyplýva z jeho spôsobov získania energie, jeho využitia, spôsobov aplikácie, klimatických podmienok a pod. Takisto jedinečná je aj každá stavba a jej unikátny spôsob návrhu riešenia situácie zariadenia staveniska. Na začiatku bolo potrebné určit' obmedzujúce kritéria a okrajové podmienky pre návrh. Ked’že kritérií na realizáciu je vel'ké množstvo, tak sme sa obrátili na tím odborníkov (stavbyvedúci na konkrétnej stavbe, odborníci na využívanie OZE a odborníci zo SHMU). Po dôkladných konzultáciách sme si zvolili za najdôležitejšie kritéria: miesto a priestor realizácie stavby, zastavanost' územia (priestory na realizáciu zariadenia staveniska), spôsoby realizácie montáže turbín (návrh technológie), druhy vhodných OZE, čas realizácie projektu, účel spotreby energie.

\subsection{Analýza priestorovej štruktúry na implementáciu veterných turbín}

Pri samotnom návrhu zariadenia staveniska pre realizáciu stavby vychádzame už z analýzy vstupných údajov, ktoré nám poskytli architekti zo situačných výkresov. Na optimálny spôsob výpočtu pre návrh veterných turbín je nutné určit' presné miesto realizácie stavby. Či je stavba dostatočne vel'ká vzhl'adom k obostavanému priestoru (priestor na realizáciu zariadenia staveniska) a či sa nachádza v obytnej zóne. Podl'a toho sa dá zistit' priemerná rýchlost'/sila vetra na príslušnú oblast'. Treba vychádzat' min. zo zmien za posledných 5 rokov, podl'a SHMÚ alebo z miestnych meteorologických staníc. Každá meracia stanica má svoje špecifické vlastnosti merania.

\subsection{Zastavanost' územia}

Kl'účovým prvkom na uskutočnenie realizácie veterných turbín je nutnost' existencie realizácie zariadenia staveniska. Pretože, ak by bola zastavanost' budúceho objektu takmer na celom pozemku, bez možnosti realizácie návrhu unimobuniek na stavenisku, tak by sa neuskutočnila realizácia montáže veterných turbín z hl'adiska efektivity - minimalizovat' straty. Podl'a vyššie uvedených odborníkov sa odporúča inštalovat' malé veterné turbíny min $5 \mathrm{~m}$ nad terén. Avšak čím vyššie, tým lepšie. Takisto meteorologické stanice sú tiež nastavené na miesto merania v rozhraní $5-10 \mathrm{~m}$ nad terénom. Vzhl'adom na ekonomickú efektívnost', celkový čas od začatia projektu až po dokončenie by mal trvat' min. 18 mesiacov.

\subsection{Technologický návrh realizácie veterných turbín na stavbe}

Aby bol návrh správny, ktorý typ veterných turbín z ponuky vybrat' na daný objekt, bolo potrebné získat' hlavné parametre pre danú lokalitu i objekt. Jedným z najdôležitejším parametrov bola priemerná rýchlost' vetra v danom okolí objektu, Bratislava - Petržalka City, výška budúceho objektu, či je stavba v zastavanom území alebo vol’ne stojaca, či okolo objektu sa nenachádzajú vyššie budovy, alebo či sa nenachádza $\mathrm{v}$ ochrannom pásme a podobne.

Podl'a záznamov môžeme predpovedat', že rýchlost' vetra je stála, že sa vel'mi nemení. Priemerná rýchlost', s ktorou budeme počítat' je $3,8 \mathrm{~m} / \mathrm{s}$. Táto rýchlost' je meraná anemometrom vo výške $10 \mathrm{~m}$. Pre návrh - rýchlost' vetra bude iná, po zohl'adnení meraní a matematickom spracovaní - analýze časových radov. Budeme musiet' brat' do úvahy získaný koeficient polôh zo vzt'ahu, ktorý bol vypočítaný pre polohu A koeficientom $\mathrm{k}=0,96$. Finálna rýchlost' bude upravená týmto vzt'ahom $3,8 \mathrm{~m} / \mathrm{s}$ x $0,96=3,648 \mathrm{~m} / \mathrm{s}$. 
Podl'a výkonu jedna veterná turbína dokáže vyrobit' $215 \mathrm{kWh}$ za mesiac. Je potrebne pokryt' $771 \mathrm{kWh}$ na mesiac. $Z$ toho vyplýva, že budeme potrebovat' 3,58 turbíny na pokrytie spotreby. Pre návrh na zabezpečenie osvetlenia zariadenia staveniska vybranej stavby Bratislava-Petržalka City 2 budú potrebné štyri kusy veterných turbín typu WG-100. Ich návrh je znázornený na obr. 2. Oranžová šípka znázorn̆uje ocel’ové lana. Modrá farba znázorňuje ukotvenú turbínu, šedá farba je základ pre položenie a kotvenie veternej turbíny.

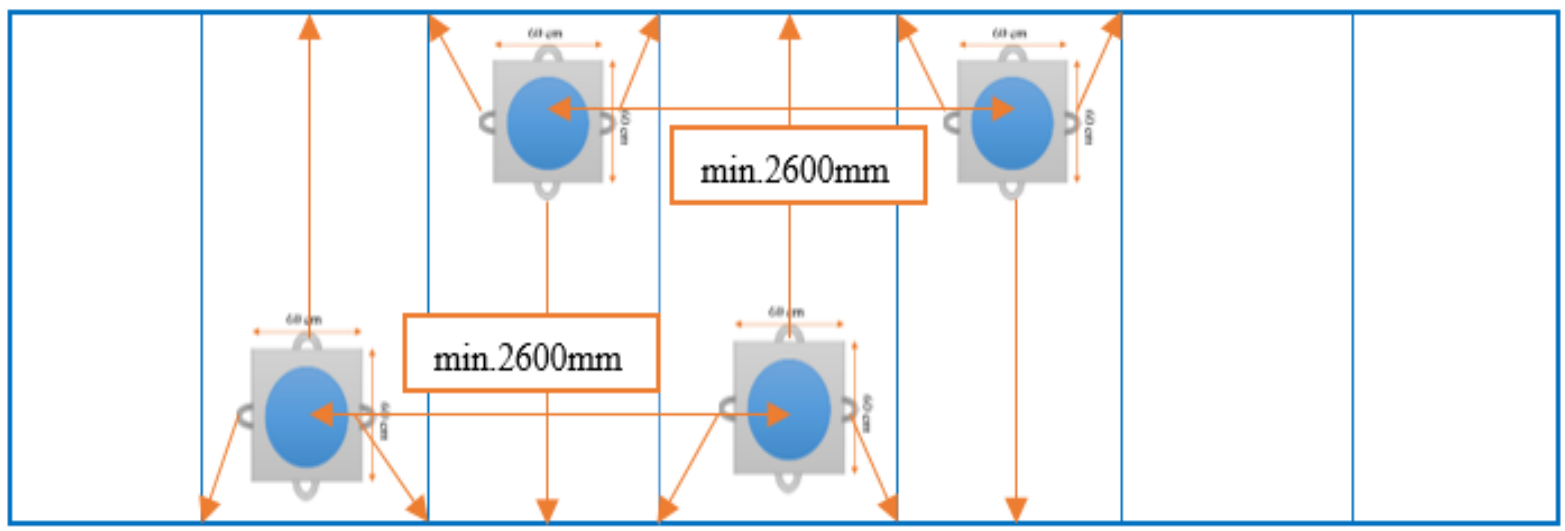

Obr. 2 Návrh uloženia veterných turbín na pôdoryse strechy unimobuniek, zdroj: autor

Priestor na inštaláciu veterných turbín je dostatočne vel'ký. Montáž nad strechou obytných kontajnerov má vel'kú výhodu nielen vo výške umiestnenia turbíny, ale miesto uloženia kontajnerov je navrhnuté tak, aby sa tam neotáčal žeriav s bremenom, čím sa znižuje riziko zrážky. [5]

Výkon generátora záleží na rýchlosti vetra. Výrobca uvádza výkon, ktorý je schopný vyprodukovat' veterná turbína za daný jeden mesiac pri rôznych rýchlostiach. Vplyv na produkciu energie záleží nielen na rýchlosti vetra, ale vel'mi dôležité je aj prostredie, kde je umiestnená. Rýchlost' nárazu a schopnost' vytvorit' pritom vírivý pohyb, ktorý uvedie turbínu do prevádzky.

\section{ZÁVER}

Technologický náskok v oblasti alternatívnych zdrojov energie a znižovanie spotreby energie vytvoria vel'ké príležitosti pre vývoz a priemysel. Tým sa zároveň podporí rast a zamestnanost'. Obnovitel'né zdroje energie budú pri prechode na systém čistej energie zohrávat' významnú úlohu. [4]

Slovenská republika disponuje dostatočným potenciálom obnovitel’ných zdrojov energie. Z OZE sa najviac preferuje slnečná energia a biomasa. Slovensko je vnútro kontinentálna krajina, napriek tomu má dostatočný technický potenciál na využívanie veternej energie . Tento potenciál však takmer nevyužíva. Vel'mi dobrým príkladom môže byt' susedné Rakúsko, ktoré efektívnym spôsobom buduje veterné farmy. Jedným z dôležitých faktorov zostáva podpora zo strany štátu.

Navrhnutá metodika je aplikovatel’ná na akejkol'vek stavbe. Každá stavba je jedinečná tým, že je vždy na inom mieste a realizuje sa $\mathrm{v}$ iných podmienkach. Východiskom pre návrh veterných turbín na zariadenie staveniska je meranie rýchlosti vetra na určenom mieste už od začiatku návrhu stavby a následne zistenie nameraných dát od lokálnych meteostaníc. Získané výsledky môžu byt' podkladom pri návrhu projektu organizácie výstavby v čase prípravy a realizácie stavebných objektov.

Výsledky z aplikovaného príkladu podl’a navrhovanej metodiky ukazujú na to, že návrh implementácie veterných turbín je možný realizovat’ v konkrétnych podmienkach aj na Slovensku. 


\section{Použitá literatúra}

[1] COP 21: Parlament zadefinoval ciele pre klimatickú konferenciu v Pariži. [online] 14/10/2015. [citované 10/01/2018]. Dostupné na: http://www.europarl.europa.eu/news/sk/news-room/20151013IPR97324/COP-21-Parlamentzadefinoval-ciele-pre-klimatick\%C3\%BA-konferenciu-v-Par\%C3\%AD\%C5\%BEi

[2] MF SR: Moderné a úspešné Slovensko. [online] 10/2020, [citované 01/12/2020]. Dostupné na: https://www.mfsr.sk/sk/financie/institut-financnej-politiky/strategicke-materialy/inestrategicke-materialy/

[3] MH SR: Inovácie hýbu svetom, dôležité sú aj venergetike. [online] 03/2019, [citované 10/11/2020]. Dostupné na: https://www.mhsr.sk/press/inovacie-hybu-svetom-dolezite-su-ajv-energetike

[4] MH SR: Integrovaný národný energetický a klimatický plán na roky 2021-2030. [online] https://www.mhsr.sk/uploads/files/zsrwR58V.pdf

[5] PASKA, J., T. SURMA, 2014. Electricity Generation from Renewable Energy Sources in Poland, Renewable Energy Volume 71, November 2014, pp. 286-294.

[6] Podiel OZE na Slovensku vzrástol o pol percenta, za priemerom EÚ zaostávame. Eurostat. [online] 24.01.2020 [citované 24/11/2020] Dostupné na: https://www.energieportal.sk/Dokument/podiel-oze-na-slovensku-vzrastol-o-pol-percenta-za-priemerom-euzaostavame-105765.aspx

[7] Využitie plného potenciálu OZE by Slovensko stálo 22 miliárd eur. IRENA. [online] 23/11/2020. [citované 24/11/2020] Dostupné na: https://www.energieportal.sk/Dokument/vyuzitie-plneho-potencialu-oze-by-slovensko-stalo-22-miliard-eur106617.aspx

[8] Zelená domácnostiam. [online] 09/2020. [citované 24/11/2020]. Dostupné na: http://zelenadomacnostiam.sk/sk/ 